\title{
Penyuluhan Hukum Bahaya Bullying di Kalangan Remaja
}

\author{
Setiawati ${ }^{\mathbf{a} 1}$ \\ aprogram Studi Pendidikan Pancasila dan Kewarganegaraan, Fakultas Keguruan dan Ilmu Pendidkan, \\ Universitas Pamulang, Tangerang Selatan* \\ ${ }^{1}$ dosen02084@unpam.ac.id \\ *korespondensi penulis
}

Naskah diterima: 17 November 2020, direvisi: 10 Januari 2021, disetujui: 27 Februari 2021

\begin{abstract}
Abstrak
Masa remaja merupakan masa yang penuh dengan dinamika yang mana pada masa ini banyak terjadi perubahan dan perkembangan yang pesat. Pada masa ini merupakan masa transisi yang mempunyai banyak resiko yang terjadi, tingginya kenakalan dan kekerasan baik sebagai korban maupun sebagai pelaku tindak kekerasan.Peristiwa demi peristiwa tindak kekerasan (bullying) masih terus terjadi di beberapa wilayah. Berdasarkan latar belakang tersebut, kami dari Tim Program Pengabdian Masyarakat (PKM) Universitas Pamulang (UNPAM) yang terpanggil untuk ikut serta berbagi pengetahuan kepada para remaja pulau Untung Jawa terkait bullying dengan mengadakan PKM dengan judul" Penyuluhan Hukum Bahaya Bullying di Kalangan Remaja". Kegiatan pengabdian ini dilakukan dengan cara memberikan penyuluhan kepada remaja di Pulau Untung Jawa. Selain itu juga diadakan sesi Tanya jawab antara tim pengabdi dengan remaja di pulau untung Jawa agar mereka tau dan dapat membedakan lebih banyak lagi hal-hal yang disebut dengan candaan dan yang dikategorikan bullying, mengingat bullying tidak hanya secara fisik tetapi juga secara verbal.

Kata-kata kunci: remaja;resiko;bullying.
\end{abstract}

Abstract

Adolescence is a time of being filled with the dynamics of which at this time many changes and rapid developments occur. During this time the transition has a lot of risks, high mischief and violence both as victims and as perpetrators of violent acts. Events in the event of violent acts (bullying) continue to occur in some areas. Based on the background, we are from the community service Program (PKM) University of Pamulang (UNPAM) which is called to share knowledge to the young island of Untung Java regarding bullying by holding a PKM with the title " Legal counseling for Bullying among adolescents. "This dedication activity is done by providing counseling to teenagers in Untung Java island. In addition, the question and answer session between the youth team in the island of Java is profitable to know that they can distinguish more of the things that are called by joked and categorized bullying, considering bullying is not only physically but also verbally.

Keywords: Adolescents: Risk; Bullying. 


\section{PENDAHULUAN}

Masa remaja merupakan masa yang penuh dengan dinamika yang mana pada masa ini banyak terjadi perubahan dan perkembangan yang pesat. Pada masa ini merupakan masa transisi yang mempunyai banyak resiko yang terjadi, tingginya kenakalan dan kekerasan baik sebagai korban maupun sebagai pelaku tindak kekerasan.

Peristiwa demi peristiwa tindak kekerasan (bullying) masih terus terjadi di beberapa wilayah. Kasus kekerasan ini telah lama terjadi di Indonesia, namun luput dari perhatian. Yogyakarta terkenal sebagai kota pelajar, ternyata potensial pula menjadi kota kekerasan. Penelitian yang dilakukan kluster Penelitian Sosial Humaniora UGM menunjukkan kasus bullying (tindak kekerasan) di sekolah-sekolah Yogyakarta lebih tinggi dari Jakarta dan Surabaya, bahkan potensi kekerasan di Yogyakarta melebihi kota Palu yakni 70,65\% kasus bullying di tingkat SMP dan SMA. Budaya bullying di Yogyakarta terbangun dengan banyaknya fenomena geng dan pengkaderan yang dilakukan alumni sekolah.
Pengertian bullying menurut Komnas HAM (Hak Asasi Manusia) adalah sebagai suatu bentuk kekerasan fisik dan psikologis berjangka panjang yang dilakukan seseorang atau kelompok terhadap seseorang yang tidak mampu mempertahankan diri dalam situasi ada hasrat untuk melukai atau menakuti orang atau membuat orang tertekan, trauma atau depresi dan tidak berdaya. Kebiasaan pengeroyokan sebagai bentuk main hakim sendiri dalam menyelesaikan pertikaian atau konflik juga tampak sangat kuat di kalangan pelajar. Hal ini tentunya sangat memprihatinkan, karena mencerminkan suatu kehidupan yang tidak beradab yang semestinya dalam menyelesaikan persoalan (konflik) dilakukan dengan cara-cara yang bermartabat. Para pelaku umumnya mencontoh situasi serupa yang terjadi di lingkungannya.

Menurut Undang-Undang Hak Asasi Manusia Pasal 17 Undang-Undang Nomor 39 Tahun 1999 tentang Hak Asasi Manusia, bahwa setiap orang tanpa diskriminasi, berhak untuk memperoleh keadilan dengan mengajukan permohonan, pengaduan dan gugatan, baik dalam perkara pidana, perdata, maupun adiministrasi serta diadili melalui proses peradilan yang 
bebas dan tidak memihak, sesuai dengan hukum acara yang menjamin pemeriksaan yang objektif oleh hakim yang jujur dan adil untuk memperoleh putusan yang adil dan benar. Ironisnya lagi sebagian masyarakat kita bahkan guru sendiri menganggap bullying sebagai hal biasa dalam kehidupan remaja dan tak perlu dipermasalahkan, bullying hanyalah bagian dari cara anakanak bermain.

Yayasan SEJIWA mengidentifikasi jenis dan wujud bullying secara umum dapat dikelompokan ke dalam tiga kategori (Yayasan Semai Sejiwa, 2008: 2), yaitu:

a) Bullying Fisik

Meliputi tindakan: menampar, menimpuk, menginjak

kaki,menjegal, meludahi, memalak, melempar dengan barang, menghukumdengan berlari keliling lapangan dan menghukum dengan cara push up.

\section{b) Bullying Verbal}

Terdeteksi karena tertangkap oleh indera pendengaran,seperti memaki, menghina, menjuluki, meneriaki, memalukan di depan umum, menuduh, menyoraki, menebar gosip, memfitnah dan menolak.

\section{c) Bullying Mental}

Mental/Psikologis, merupakan jenis bullying yang paling berbahaya karena tidak tertangkap mata. Praktik ini terjadi secara diam-diam dan di luarpemantauan si korban. Contohnya adalah: memandang sinis, memandang penuh ancaman, mempermalukan di depan umum, mendiamkan, mengucilkan, mempermalukan, meneror lewat pesan sms, memandang yang merendahkan, memelototi, dan mencibir.

Setiap anak dan remaja yang terlibat secara langsung (pelaku dan korban), tidak langsung, dan yang tidak terlibat sekali pun,berpotensi mengalami bullying. Salah satu alasan dari banyaknya tindak kekrasan (bullying) yang terjadi di kalangan anak dan remaja dapat diurai berdasarkan hasil survei, bahwa sebagian besar korban enggan menceritakan pengalaman mereka kepada pihak-pihak yang mempunyai kekuatan untuk mengubah cara berpikir mereka dan menghentikan siklus ini. Korban biasanya merahasiakan bullying yang mereka derita karena takut pelaku akan semakin mengintensifkan Bullying mereka (AniesWidiyawati, 2014: 2). Oleh karena keengganan atau ketakutan korban untuk menceritakan perilaku bullying 
tersebut, pencegahan bullying ini pun menjadi terhambat. Faktor keluarga, teman sebaya, dan sekolah membentuk perilaku bullying pada remaja. Meskipun dalam persentase yang kecil bullying juga berdampak terhadap kecenderungan depresi pada remaja, di mana depresi tersebut berakibat adanya pikiran untuk melakukan bunuh diri dan melukai diri.

Berdasarkan latar belakang tersebut, kami dari Tim Program Pengabdian Masyarakat (PKM) Universitas Pamulang (UNPAM) yang terpanggil untuk ikut serta berbagi pengetahuan kepada para remaja pulau Untung Jawa terkait bullying dengan mengadakan PKM dengan tema" Penyuluhan Hukum Bahaya Bullying di Kalangan Remaja".

Beberapa penelitian menunjukkan bahwa kejadian bullying memiliki kaitan dengan kejadian bunuh diri dan depresi pada anak-anak dan remaja. Sebuah review dari berbagai artikel penelitian yang terkait dengan dampak bullying terhadap kejadian bunuh diri menunjukkan bahwa anak-anak yang mengalami bullying memiliki risiko yang cenderung lebih tinggi untuk memiliki ide bunuh diri atau pernah mencoba untuk bunuh diri (The Association of Bullying, 2010). Penelitian oleh Schneider, et al. (2012) juga menunjukkan bahwa korban bullying memiliki tingkat tekanan mental yang lebih tinggi, dengan kejadian depresi dan keinginan bunuh diri masing-masing sebesar $4.38 \%$ dan $5.35 \%$. Korban bullying juga disebutkan mengalami penurunan pre7stasi belajar di sekolah dan lebih sering absen dari sekolah (Schneider, et al, 2012).

METODE

Pengabdian masyarakat ini dilaksanakan di Kelurahan Pulau Untung Jawa dengan target sasarannya adalah remaja karang taruna yang berada di kelurahan tersebut.

Adapun metode yang digunakan pada pengabdian masyarakat ini di lakukan dengan cara memberikan penyuluhan kepada remaja karang taruna di PulauUntung Jawa tentang bahaya bullying di kalangan remaja.

Materi penyuluhan ini disampaikan langsung oleh ketua pengabdi yaitu ibu Setiawati, penyampaian materi ini di lakukan kurang lebih selama 60 menit dengan di akhiri dengan diskusi tanya jawab bersama para remaja Kelurahan Pulau Untung Jawa.

\section{HASIL DAN PEMBAHASAN}

Pengabdian kepada masyarakat yang dilakukan dengan tema Bahaya Bullying di kalangan remaja ini memfokuskan pada pencegahan terjadinya bullying di kalangan remaja. Penyuluhan ini diawali dengan membagikan angket untuk diisi oleh para 
peserta untuk mengetahui wawasan mereka terkait jenis-jenis bullying. Setelah itu dilanjutkan dengan penyampaian jenis-jenis bullying yang sering terjadi di kalangan remaja.

Penyampaian jenis-jenis bullying yang sering terjadi ditampilkan dalam bentuk tayangan video sehingga para remaja dapat melihat langsung contoh jenis bullying yang terjadi baik secara fisik maupun secara verbal.

Selain itu pada kesempatan ini juga disampaikan bahaya bullying bagi si pelaku maupun bagi si korban.

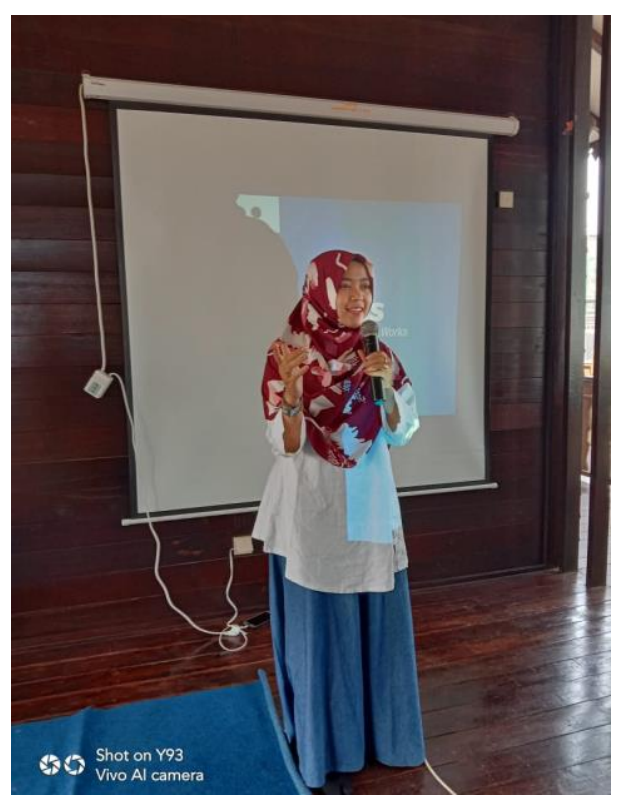

Gambar 1. Nara sumber sedang menjelaskan materi

Pada saat pemutaran tayangan video jenis-jenis bullying ternyata banyak remaja yang masih belum mengetahui bahwa perilaku mereka termasuk candaan yang mereka lakukan termasuk kedalam kategori bullying baik fisik maupun verbal.

Di sela sela penyampaian materi juga diselingi tanya jawab bersama para remaja karang taruna,mereka sangat antusias menanyakan banyak petanyaan terkait permasalahan bullying yang sering mereka lihat, mereka temui atau bahkan sesuatu yang mereka anggap selama ini sebuah candaan apakah termasuk kedalam kategori bullying atau tidak.

Beberapa pertanyaan yang diajukan oleh peserta pengabdian ini diantaranya oleh saudara Ardi, dia mengatakan “ apakah jika kita mengejek teman dengan mengatainya pendek, padahal kenyataannya memang dia pendek apakah itu termasuk termasuk bullying "?

Mendengar pertanyaan yang dilontarkan oleh saudara Ardi nara sumber langsung menjawabnya dengan menjelaskan bahwa bullying tidak hanya berupa kejahatan fisik seperti memukul, menendang atau mencekik, mengejek teman dengan mengatainya pendek itupun termasuk kategori bullying yang disebut dengan bullying verbal atau yang diucapkan berupa kata kata.

Artinya kita semua harus berhati hati dalam melontarkan kata candaan, atau bisa diganti dengan candaan lain yang tidak menyebutkan hal-hal yang terkesan 
merendahkan seseorang. Mengatai seseorang pendek tentu akan membuat orang tersebut merasa malu atau bahkan minder untuk bergaul dengan teman yang lebih tinggi darinya.

Selain pertanyaan ardi banyak juga pertanyaan pertanyaan lain yang diajukan oleh peserta pengabdian. Bahkan ada salah satu peserta yang mengatakan bahwa sebaiknya kegiatan pengabdian seperti ini dapat dilakukan secara berkala ditempat mereka ini sehingga mereka dapat mendapatkan pengetahuan seperti teman teman mereka yang tinggal di kota besar.

Nara sumber menjawab pertanyaan mereka satu persatu dengan penuh semangat hingga semua pertanyaan yang diajukan terjawab seluruhnya.

Setelah diberikan pemaparan terkait materi jenis bullying wawasan remaja terkait hal tersebut meningkat terbukti dengan hasil pengisian angket yang dibagikan oleh tim pengabdian kepada para remajadi pulau untung jawa.

\section{KESIMPULAN}

Remaja merupakan generasi penerus bangsa yang banyak mempunyai peluang untuk maju. Bullying merupakan salah satu tindakan yang menyebabkan remaja terpuruk sehingga harus ditangani dengan baik agar tidak terjadi terus menerus di kalangan remaja, karena bullying dapat merusak masa depan remaja.

Kegiatan pengabdian kepada masyarakat ini merupakan salah satu tri dharma perguruan Tinggi yang diharapkan dengan adanya kegiatan dapat memberikan kontribusi nyata kepada masyarakat di bidang sosial khususnya dalam meningkaktan kesadaran pada remaja terkait bahaya bullying di kalangan remaja, mengingat kasus ini kerap sekali terjadi dikalangan remaja.

Pentingnya pengetahuan tentang hukum sangatlah perlu diberikan kepada remaja penerus bangsa kita agar mereka terhindar dari perilaku-perilaku yang menyimpang ataupun perilaku yang bertentangan dengan hukum yang berlaku, sehingga mereka dapat terhindar dari kasus kasus hukum yang dapat menjerat mereka akibat ketidaktahuannya terhadap suatu kegiatan atau tindakan yang mereka anggap sebuah candaan justru dapat membuat mereka terjerat kasus hukum.

\section{UCAPAN TERIMAKASIH}

Terima kasih penulis haturkan kepada semua pihak yang telah membantu terlaksananya kegiatan Pengabdian Masyarakat ini terutama dosen Prodi Pendidikan Pancasila dan Kewarganegaraan Fakultas Keguruan dan IlmuPendidkan Universitas Pamulang, para mahasiswa, Lurah Pulau Untung jawa serta Karang taruna Remaja kelurahan Untung Jawa. 
Semoga apa yang telah diperbuat menjadi

ladang amal soleh bagi kita semua.Aamiin.

\section{REFERENSI}

Assegaf, Abd. Rahman. (2004) . Pendidikan Tanpa Kekerasan : Tipologi Kondisi, Kasus dan Konsep. Yogya: penerbit Tiara Wacana.

Coloroso, Barbara. (2006). Penindas, Tertindas dan Penonton. Resep Memutus Rantai Kekerasan
Anak dari Prasekolah Hingga SMU. Jakarta: Serambi.

Davidoff. Linda L. (1991). Psikologi Suatu pengantar. Edisi Kedua. Jakarta: Penerbit ErlanggaLachenmeyer. 